\title{
Application of soil solarization to control root-knot nematodes and weeds in transplanted tomato
}

\author{
A. G. CARSON \&E. OTOO \\ School of Agriculture, University of Cape Coast, Cape Coast, Ghana
}

\section{SUMMARY}

The effects of $0,10,20$ and 30 days of tightly covering of tomato beds with thick $(50 \mathrm{~m} \mu)$ transparent polyethylene plastic sheet prior to transplanting were assessed on soil temperatures, root-knot nematodes, specific weeds, and growth and fruit yield of tomato in a field experiment at the Teaching and Research Farm of the University of Cape Coast in 1992. Mean soil temperatures ranged from 44 to $53{ }^{\circ} \mathrm{C}$ at $5 \mathrm{~cm}$ depth and from 36 to $46{ }^{\circ} \mathrm{C}$ at $10 \mathrm{~cm}$ depth with temperatures increasing with successive increases in period of solarization. Soil nematodes, mostly root-knot (Meloidogyne spp.) were significantly reduced and the longer the period of solarization the greater was the reduction. Root-galling incidence in tomato was likewise reduced significantly by solarization. Annual weed species which reproduce by means of numerous tiny seeds, including Boerhavia diffusa, Ageratum conyzoides, Euphorbia heterophylla and Tridax procumbense, were effectively controlled particularly by long periods of solarization. On the other hand, Cynodon dactylon which reproduces vegetatively by stolons was partially controlled. The predominant weed species Cyperus rotundus, a perennial, could not be controlled even by the longest period of solarization. Soil solarization also improved crop height and fruit yield. This is attributed possibly to its lethal effect on nematodes, weeds and its favourable influence on mineralization of soil organic matter, and reduction in fruit decay incidence.

Original scientific paper. Received 2 Apr 96; revised 30 Oct 96.

\section{Introduction}

Tomato is one of the most important and widelycultivated indigenous vegetables in Ghana. It is mostly used as a condiment in soups, gravy, stew and to a lesser extent as fresh vegetable in salads.

\section{RÉSUME}

CARSON, A G. \& OTOO, E. : L'Application de solarisation du sol pour le contrôle de nématodes de neeud radical et de mauvaises herbes en tomate repiquée. Le effets de $0,10,20$, et 30 jours de couverture de planches de tomate avec un morceau de plastique polyéthyléne transparent et épais ( $50 \mathrm{m \mu}$ ) préalablement à la transplantation étaient évalués sur les températures du sol, le nématode de nœeud radical, les mauvaises herbes spécifiques, la croissance et le rendement fruitier de tomate dans une expérience sur le terrain au champs de recherche et d' enseignment d' Université de Cape Coast et 1992. Les températures moyennes du sol varient de 44 à $53^{\circ} \mathrm{C}$ à $5 \mathrm{~cm}$ de profondeur et de $36 \dot{\mathrm{a}} 46^{\circ} \mathrm{C} 10 \mathrm{~cm}$ de prafondeur avec une augmentation des températures conformément aux augméntations successives de la période de solarisation. Les nématodes du sol, surtout les nceuds radicaux (Meloidogyne spp.) étaient considérablement reduits et plus grande était la reduction lorsque la période de solarisation était plus longue. $L$ 'incidence de galle-racine était également reduit considérablement par la solarisation. Les espéces de mauvaise herbe annuelle qui se reproduisent par le moyen de plusieurs granes minuscules, y compris Boerhavia diffusa, Ageratum conyzoides, Euphorbia heterophylla et Tridax procumbense étaient efficacement contrôlés surtout par le longues périodes de solarisation. De l' autre côté Cynodon dactylon qui se reproduit végétativement par stolons était partiellement contrôlé. Les espéces de mauvaise herbe prédominante, Cyprus rotundus, une plante vivace ne pourrait pas être contrôlée même par la plus longue période de solarisation. La solarisation du sol améliorait également la hauteur culturelle et le rendement fruitier. Ceci est attribué possiblement à son effet léthifère sur les nématodes, les mauvaises herbes et son influence favorablesur la minéralisation de la matiére organique du sol et la reduction en I' incidence de pourrrisament fruitier.

Production is entirely by small-scale farmers on a total of 20,000 ha, yielding about $107,000 \mathrm{t}$ (FAO, 1994). Apart from its high nutritive value in terms of vitamin $A$ and $C$, tomato contributed about 13 billion cedis $(\$ 800,000)$ to the Agricul- 
tural Gross Domestic Product (PPMED, 1991).

Yields of tomato in Ghana are relatively low and of the order of $5 \mathrm{t} / \mathrm{ha}$ compared to the mean yields of 10,20,57 and 77 tha obtained in Nigeria, the rest of Africa, Japan and Israel, respectively (FAO, 1994). Causes of the poor yields could be ascribed to the low fertility of Ghanaian soils, use of unimproved planting material, low plant population, poor soil and water management and, more importantly, to losses caused by pathogens, pests and weeds. Some of the important pathogens and pests of tomato are soil-borne and include Fusarium and bacteria wilts, nematodes and weeds (De Vay, 1991; Elmore, 1991).

To control soil-borne pests, the soil needs to be disinfected before planting or transplanting. This is seldom practised in Ghana except in tobacco, oil palm and rubber nurseries. Conventional ways of disinfecting the soil has been based on soil fumigation with volatile chemicals, steaming and, to a lesser extent, soil flooding (Dawson et al., 1965; Pullman\&DeVay, 1982). However, soilfumigation and steaming are expensive to implement and may destroy many of the beneficial soil organisms in addition to the harmful ones. Chemical fumigation has the additional risk of contributing to environmental pollution. Thus, alternative options for controlling soil-borne diseases and pests should be pursued. One such option is soil solarization.

Soil solarization hadbeen described by Stapleton $\&$ De Vay (1986) as a hydrothermal process that occurs in moist soils tightly covered by a transparent plastic sheet exposed to sunlight. It has been shown in many cases that soil solarization is as effective as fumigation or steaming.

It was considered worthwhile to test this concept with the view of assessing its advantages and limitations and how it can best be modified to suit local conditions. The objective of the study was to investigate the effects of various periods of solarization on soil temperature, root-knot nematodes, root galling incidence, weeds, vegetative growth and yield of tomatoes, and mineralization of soil organic matter.

\section{Materials and methods}

The experiment was carried out in the minor season of 1992 (August-December) on a sandy clay loam soil belonging to the Benya series of the Elmina catena (Asamoah, 1973) at the Teaching and Research Farm of the University of Cape Coast. There were four treatments of $0,10,20$ and 30 days of solarization arranged in a randomized complete blocks design and replicated five times.

The plot size was $6.75 \mathrm{~m}^{2}$ and the sides of each plot were raised into a form of bed to allow for free drainage. They were watered to a depth of $20 \mathrm{~cm}$ of the soil. Solarization was accomplished on each plot by tightly covering the surface of the individual beds with a transparent polyethylene sheet of $50 \mathrm{~m} \mu$. The overlapping ends of the sheet were buried in the soil of the drains enclosing the plot.

Soil thermometers were inserted into the various plotsat depths of 5 and $10 \mathrm{~cm}$ and soil temperatures were recorded daily at 14.00 hours GMT from August 10 to September 11, 1992. Soil samples were taken from the plots before and after solarization and analyzed for nematodes, nitrogen and carbon content as follows:

\section{Nematode counts}

Five core soil samples were taken at random along the diagonals of each plot with a $5 \mathrm{~cm}$ diameter. The column height of the auger was 10 $\mathrm{cm}$. Samples were bulked and thoroughly mixed and five samples each weighing $100 \mathrm{~g}$ taken for nematodes extraction from each plot using the Baermann's TrayTechnique(Viglierchio\& Schmitt, 1983). The nematodes were fixed in a solution of 10 ml oxalicacid, $10 \mathrm{ml}$ formaldehydeand $80 \mathrm{ml}$ distilled water and then counted under a microscope. Percentage nematode control achieved with each period of solarization was calculated as follows:

$\%$ control $=100-(x / y \times 100)$, where $\mathrm{x}=$ number of nematodes in solarized plot, $y=$ number of nematodes in unsolarized plot.

Carbon and nitrogen determination

Soil samples were analyzed for carbon, using Wackley-Black method (Blacket al. 1965), and the 
nitrogen by the micro-Kjeldahlmethod (Kjeldahl, 1883). The $\mathrm{C}: \mathrm{N}$ ratios were computed for the various, treatments.

Solarized and unsolarized soils were bioassayed as follows: Tomato seeds were nursed for 10 days and the resultant seedlings transplanted on to solarized and unsolarized plots at a spacing of 75 $\mathrm{cm}$ by $60 \mathrm{~cm}$. Routine cultural practices like watering, fertilization and desuckering were carried out as recommended.

\section{Weeds assessment}

Presence of weeds was assessed at 0 (soon after removal of the plastic sheets), 4 and 8 weeks after transplanting (w.a.t.). A quadrat measuring of 30 $\mathrm{cm}$ by $30 \mathrm{~cm}$ was randomly placed at four locations on each plot. Weeds within the quadrat were handpulled, sorted into species, counted and fresh weight of individual weed species determined. Percentage weed control (PWC) was estimated thus:

$P W C=100-(x / y \times 100)$,

where $\mathrm{x}=$ fresh weight of individual or total weed species in solarized plot, $y=$ fresh weight of individual or total weed species in unsolarized plot.

\section{Plant height}

The effect of solarization on plant growth was assessed by recording the height of plants at 5,7 , and 9 w.a.t. This was carried out on five randomly-selected plants in each plot and then converted to mean values.

\section{Fruit yield}

Total fruityield and number of rotten fruits were determined on five plants in themiddle row of each plot at harvest.

Root-knot infestation

Treatments

10 days

20 days

30 days
The extent of galling by root-knot nematode was determined by last harvest in each plot and visually assessing galling incidence on each plant using a scale of 0-5. All data except soil temperatures were statistically analyzed. The $F$-test was applied to results obtained and significant difference between means were determined using the least significant differences (LSD) test (Steel \& Torrie, 1960).

\section{Results}

The recordings of the daily maximum soil temperatures and the computed means at 5 and $10 \mathrm{~cm}$ soil depths are presented in Table 1. Much higher soil temperatures were recorded in solarized than in the unsolarized treatments. Soil temperatures increased with increasing periods of solarization at both the $5 \mathrm{~cm}$ and $10 \mathrm{~cm}$ depths. For instance, the mean soil temperature recorded in $0,10,20$ and 30 days of solarization were $38.7,44.0,46.9$ and $52.8^{\circ} \mathrm{C}$, respectively at $5 \mathrm{~cm}$ soil depth. Nearly 50 per cent increase in soil temperature was obtained with 30 days of solarization over the unsolarized treatment at the 10 $\mathrm{cm}$ depth. The daily maximum soil temperature (DMST) also increased with increasing periods of solarization at both soil depths although both the mean and DMST were relatively lower at the 10 $\mathrm{cm}$ than at the $5 \mathrm{~cm}$ soil depth in all treatments.

TABLE 1

Effect of Duration of Solarization on Soil Temperatures $\left({ }^{\circ} \mathrm{C}\right)$ at $5 \mathrm{~cm}$ and $10 \mathrm{~cm}$ Depths

Means and daily maximum soil temperature (DMST)

$5 \mathrm{~cm}$ soil depth $\quad 10 \mathrm{~cm}$ soil depth

$5 \mathrm{~cm}$ soil depth $10 \mathrm{~cm}$ soil depth

1-10 11-20 21-30 Mean DMST 1-10 11-20 21-30 Mean DMST

\begin{tabular}{lllllllllll}
\hline Nosolarization & 37.0 & 39.8 & 39.4 & 38.7 & 39.0 & 29.9 & 32.3 & 33.0 & 31.7 & 35.0
\end{tabular}

$\begin{array}{lllllllllllll}\text { solarization } & - & - & 44.0 & 44.0 & 47.0 & - & - & 36.1 & 36.1 & 44.0\end{array}$

$\begin{array}{lllllllllll}\text { solarization } & - & 48.7 & 45.0 & 46.9 & 54.0 & - & 402 & 35.2 & 37.9 & 47.0\end{array}$

$\begin{array}{lllllllllll}\text { solarization } & 48.8 & 553 & 54.4 & 52.8 & 58.5 & 41.5 & 49.0 & 48.0 & 46.2 & 49.0\end{array}$




\section{Control of nematodes and root-knot incidence}

All the solarized treatments reduced the population of nematodes significantly and the longer the period of solarization the higher the degree of nematode control (Table2). The bench mark population of soil nematodes was about 220 per $100 \mathrm{~g}$ soil with the 30 day solarization achieving near

TABLE 2

Effect of Duration of Solarization on Soil Root-knot Population and Root-galling Index in Tomato

\begin{tabular}{lccc}
\hline Treatment & $\begin{array}{c}\text { Counts of } \\
\text { nematodes/ } \\
\text { l00 g soil } \\
\text { after solar- } \\
\text { ization }\end{array}$ & $\begin{array}{c}\text { Percent } \\
\text { control of }\end{array}$ & $\begin{array}{c}\text { Root-galling } \\
\text { index * }\end{array}$ \\
\hline $\begin{array}{l}\text { No solarization } \\
10 \text { days } \\
\text { solarization }\end{array}$ & 218.2 & $0.0 \mathrm{~d}^{* *}$ & $4.5 \mathrm{a}$ \\
$\begin{array}{l}20 \text { days } \\
\text { solarization }\end{array}$ & 14.0 & $93.6 \mathrm{c}$ & $1.2 \mathrm{~b}$ \\
$\begin{array}{l}30 \text { days } \\
\text { solarization }\end{array}$ & 4.8 & $97.8 \mathrm{~b}$ & $1.0 \mathrm{~b}$ \\
\hline SE & 1.0 & $99.9 \mathrm{a}$ & $0.8 \mathrm{~b}$ \\
\hline
\end{tabular}

* Root-galling index (0-5 scale):

$$
\begin{aligned}
& 0=\text { no galling } \\
& 1=1-20 \% \text { galling } \\
& 2=21-40 \% \text { galling } \\
& 3=41-60 \% \text { galling } \\
& 4=61-80 \% \text { galling } \\
& 5=81-100 \% \text { galling }
\end{aligned}
$$

** Means within column and followed by same letter are not significantly different at $95 \%$ probability level, according to Duncan's Multiple Range Test.

ANOVA was carried out on transformed (Arc sine)

percentage data.

perfect control.

Tomato plants grown in solarized soils had significantly lower galling indices than those grown in unsolarized control soils. However, differences in incidence of galls among the solarized treatments were not significant.

\section{Weed control}

The common weeds recorded in the experi- ment were Cyperus rotundus, Cynodon dactylon (L.) Pers, Boerhavia diffusa L., Ageratum conyzoides L., Euphorbia heterophylla L. and Tridax procumbense L., in decreasing order of prevalence. Cyperus rotundus alone contributed 60 per cent of total weed biomass. Percentage weed control was determined on the basis of fresh weight of weeds at 0,4 and 8 w.a.t. and are presented in Table 3. The percentages of weed control achieved in solarized treatments were significantly greater than those obtained in unsolarized treatments at all stages of growth of the crop. Each successive increase of solarization period also added a significant increase in weed control.

However, the best percentage control of total weeds obtained with solarization was only 40 per cent and that was far below levels that could be achieved with othermeasures of weed control such as handweeding. Solarization was ineffective in the control of $C$. rotundus with the 30 days of solarization achieving only 7 per cent control prior to transplanting. By 8 w.a.t., control of $C$. rotundus had diminished to a mere 3 per cent (Table 3 ).

With regard to the annual weeds, 20-30 days of solarization achieved $75-100$ per cent weed control during the critical period of weed competition, estimated to be 6 w.a.t. in tomato.

\section{Plant height}

Fig. 1 shows the effect of solarization on the height of tomato plants at 5, 7 and 9 w.a.t. Plant height was used as a measure of the growth response of tomato to solarization and was found to be significantly higher in solarized than in unsolarized soils at all the stages of growth. Each successive increase in period of solarization also added a successive significant increase in the height of the plant. Plant height associated with 30 days of solarization (ranged from 40 to $81 \mathrm{~cm}$ ) was more than double that associated with the unsolarized soil which ranged from 22 to $40 \mathrm{~cm}$.

Fruit yield

Both the mean fruit yield per plant and number 
TABLE 3

Effect of Duration of Solarization on Weed Control at 0,4 and 8 Weeks after Transplanting (w.a.t.)

\begin{tabular}{|c|c|c|c|c|c|c|c|c|c|}
\hline \multirow{3}{*}{ Weed species } & \multicolumn{9}{|c|}{ Percentage weed control } \\
\hline & \multirow{2}{*}{\multicolumn{2}{|c|}{$\begin{array}{r}O . W . A . \\
10 D . S 20 D . S\end{array}$}} & \multirow{2}{*}{$30 D . S$} & \multicolumn{3}{|c|}{$O W$} & \multicolumn{3}{|c|}{ O.W.A.T } \\
\hline & & & & 100.5 & $20 D . S$ & $30 D . S$ & $10 D . S$ & $20 D . S$ & $30 D . S$ \\
\hline Total weeds & $12 a^{*}$ & $26 b$ & $35 \mathrm{c}$ & $21 \mathrm{a}$ & $26 b$ & $33 \mathrm{c}$ & $23 a$ & $33 \mathrm{~b}$ & $40 c$ \\
\hline Cyperus rotundus $\mathrm{L}$. & $0 \mathrm{a}$ & $\mathrm{Oa}$ & $7 b$ & $\mathrm{Oa}$ & $0 \mathbf{a}$ & $3 a$ & $\mathrm{Oa}$ & $\mathrm{Oa}$ & $3 \mathbf{a}$ \\
\hline $\begin{array}{l}\text { Cynodon dactylon } \mathrm{L} \text {. } \\
\text { (Fars) }\end{array}$ & $67 a$ & $83 b$ & $100 c$ & $50 \mathrm{a}$ & $67 \mathrm{~b}$ & $100 \mathrm{c}$ & $33 a$ & $80 \mathrm{~b}$ & $100 \mathrm{c}$ \\
\hline Boerhavia diffusa $\mathrm{L}$. & $50 \mathrm{a}$ & $100 \mathrm{~b}$ & $100 \mathrm{~b}$ & $50 \mathrm{a}$ & $90 b$ & $100 c$ & $33 a$ & $87 \mathrm{~b}$ & $100 c$ \\
\hline $\begin{array}{l}\text { Ageratum } \\
\text { conyzoides L. }\end{array}$ & $45 a$ & $100 \mathrm{~b}$ & $100 b$ & $50 \mathrm{a}$ & $100 \mathrm{~b}$ & $100 b$ & $50 \mathrm{a}$ & $75 b$ & $100 c$ \\
\hline $\begin{array}{l}\text { Euphorbis } \\
\text { heterophylla L. }\end{array}$ & $30 a$ & $100 \mathrm{~b}$ & $100 \mathrm{~b}$ & $100 \mathrm{a}$ & $100 \mathrm{a}$ & $100 \mathrm{a}$ & $50 \mathrm{a}$ & $100 b$ & $100 \mathrm{~b}$ \\
\hline $\begin{array}{l}\text { Tridax procumben } \\
\text { L }\end{array}$ & $40 a$ & $100 b$ & $100 \mathrm{~b}$ & $100 \mathrm{a}$ & $100 \mathrm{a}$ & $100 \mathrm{a}$ & $50 \mathrm{a}$ & $75 b$ & $100 c$ \\
\hline
\end{tabular}

* Means within rows and followed by similar letters are not significantly different at $95 \%$ probability level, according to Duncan's multiple Range Test.

ANOVA was carried out on transformed (Arc Sine) percentage data. of plants in solarized soils over those in unisolarized soil. Fruit yield was increased from $0.2 \mathrm{~kg} / \mathrm{plant}$ in unsolarized soil to 3.2 $\mathrm{kg} / \mathrm{plant}$ in soil solarized for 30 days. Similarly, there was an increase in fruit numbers per plant from 3.0 in unsolarized soil to 30 in soil solarized for 30 days. Yield and fruit numbers of tomato were significantly increased by each successive increase in period of solarization. Solarization also reduced the incidence of fruit decay. Generally,

TABLE 4

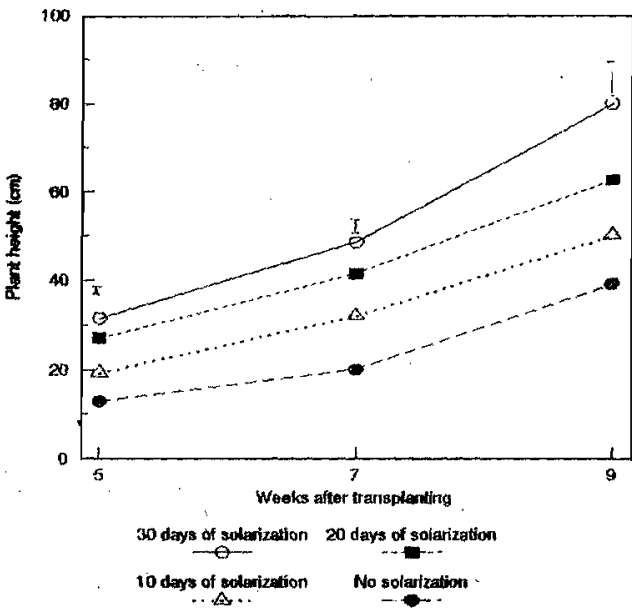

Fig. 1. Effect of duration of solarization on the height of tomato plants

of fruits per plant were significantly increased by solarization (Table 4). There was more than a thousand-fold increase in yield and fruit numbers
Effect of Duration of Solarization on Tomato Yield and C:N Ratio of the Soil

\begin{tabular}{lccccc} 
& \multicolumn{2}{c}{ Fruit yield parameters } & \multicolumn{2}{c}{ C:N ratios } \\
\cline { 2 - 6 } Treatment & $\begin{array}{c}\text { Mean } \\
\text { fruit wt/ } \\
\text { plant } \\
(\mathrm{kg})\end{array}$ & $\begin{array}{c}\text { No. of } \\
\text { fruits/ } \\
\text { plant }\end{array}$ & $\begin{array}{c}\text { No. of } \\
\text { rotten } \\
\text { fruits/ } \\
\text { plant }\end{array}$ & $\begin{array}{c}\text { Before } \\
\text { solariza- solariza- } \\
\text { tion }\end{array}$ & $\begin{array}{c}\text { After } \\
\text { tion }\end{array}$ \\
\hline $\begin{array}{l}\text { No } \\
\text { solarization }\end{array}$ & $0.2 \mathrm{a}^{*}$ & $3.0 \mathrm{a}$ & $10.2 \mathrm{a}$ & $40.1: 1$ & $42.2: 1$ \\
$\begin{array}{l}10 \text { days } \\
\text { solarization }\end{array}$ & $1.3 \mathrm{~b}$ & $10.0 \mathrm{~b}$ & $5.0 \mathrm{~b}$ & $39.2: 1$ & $16.7: 1$ \\
$\begin{array}{l}20 \text { days } \\
\text { solarization }\end{array}$ & $2.2 \mathrm{c}$ & $21.0 \mathrm{c}$ & $2.0 \mathrm{c}$ & $402: 1$ & $15.1: 1$ \\
$\begin{array}{l}\text { 30 days } \\
\text { solarization }\end{array}$ & $3.2 \mathrm{~d}$ & $30.0 \mathrm{~d}$ & $1.1 \mathrm{~d}$ & $40.0: 1$ & $12.1: 1$ \\
\hline SE & 0.2 & 2.3 & 0.8 & & \\
\hline
\end{tabular}

* Means within columns and followed by similar letters are not significantly different at $95 \%$ probability level, according to Duncan's Multiple range Test. 
the longer the period of solarization the greater the reduction in fruit decay. Thirty days of solarization was able to reduce the number of rotten fruits per plant from 10.2 in unsolarized treatment to 1.1 per plant.

The effect of solarization on $\mathrm{C}: \mathrm{N}$ ratios are presented in Table 4. The longer the period of solarization the narrower was the $\mathrm{C}: \mathrm{N}$ ratios. For example, $C:$ Nratios in soils solarized for $0,10,20$ and 30 days were $42: 2: 1,16: 7: 1,15: 1: 1$, and $12: 1: 1$, respectively.

\section{Discussion}

From the results, it was evident that the use of a thick transparent polyethylene sheet as a cover for moist soil for variable periods prior to transplanting of tomato, could provide an alternative means of ridding the soil of root-knot nematodes and some weeds.

Transparent polyethylene was used instead of its coloured counterpart because it has been found to be transparent to solar radiation (280-2500 nm) and in addition much less transparent to terrestrial radiation thus reducing the escape of heat from the soil(De Vay, 1991). Only red plastic sheethas been found to be relatively better in generating soil temperature than the transparent plastic sheet (Alkayssi \& Alkaraghouli, 1991).

With regard to the thickness of the plastic sheet, even though the thinner polyethylene sheet was known to be more effective in solar heating of soil, a thicker polyethylene sheet of $50 \mathrm{m \mu}$ thickness was preferred because of its higher tensile strength and resistance to puncturing and tearing by emerging leaves of perennial weeds such as Imperata cylindrica and Cyperus rotundus.

Exposure of nematodes within the $5 \mathrm{~cm}$ depth zone to temperatures of $44-52^{\circ} \mathrm{C}$ for periods of 10 - 30 days proved very lethal. This was expected since mean soil temperatures and period of exposure were far in excess of the minimum threshold of $42-43^{\circ} \mathrm{C}$ and $\mathrm{a}$ few hours of exposure established by Greco, Brandonisio \& Elia (1985) as required to kill nematodes. Although below threshold mean temperatures of $36-30^{\circ} \mathrm{C}$ were obtained at
$10 \mathrm{~cm}$ soil depth for 10 and 20 days of solarization, which by itself would not prove lethal to nematodes, their corresponding threshold daily maximum soil temperatures of $44-49{ }^{\circ} \mathrm{C}$ could, as indicated by Stapleton \& De Vay (1986), require only minutes of exposure to reach ${ }^{\mathrm{LD} 90}$ level.

The lethal action of high soil temperature on nematodes was reported by Sundaram (1986) and Brock (1978) to be mediated through disruption of the fluidity, eventual breakdown of the cell membrane, and inactiviation of respiratory enzymes. In addition, high soil temperatures could also weaken the cells of nematodes and render them susceptible to soil fumigants, e.g. the ammonia and heattolerant antagonistic microorganisms.

Generally, the degree of weed control appeared to depend on the period of solarization as well as the species of the weeds concerned. More than 10 days of solarization was required to achieve significant control of most of the weed species. Annual weeds, including Boerhavia diffusa, Ageratum conyzoides, Euphorbia hirta, and Tridax procumbense, which reproduce by numerous tiny seeds, appeared to be effectively controlled by more than 10 days of solarization up to and beyond the 8 weeks of critical weed competition period. The tiny seeds of these species were found to be very sensitive to temperature, requiring as low as $4 \mathrm{~h}$ of exposure at $40^{\circ} \mathrm{C}$ to reduce germination and $8 \mathrm{~h}$ to kill all imbibed seeds (Elmore, 1991).

The perennial weeds were not controlled to the same extent as the annual weeds, probably as a result of the bulk and moisture content of the vegetative propagules which would require higher soil temperature and longer period of solarization to effect dessication. For that matter, Cynodon dactylon which reproduces by means of fine stolons was relatively better controlled than $C y p e r u s$ rotundus. Ability of $C$. rotundus to withstand solarization was mainly due to a combination of the high population of the tubers $\left(1500\right.$ per $\left.\mathrm{m}^{2}\right)$, the size of the tubers (1g per tuber) and the depth within which they were produced $(20 \mathrm{~cm}$ depth). It would then appear that exposure of the tubers to even the 
highest mean temperatures of $52.8^{\circ} \mathrm{C}$ and $46.2^{\circ} \mathrm{C}$ attained at 5 and $10 \mathrm{~cm}$, respectively, after $30^{\circ}$ days of solarization were not enough to desiccate the imbibed tubers. Consequently, C. rotundus was virtually unchecked by solarization in this trial despite claims to the contrary that it could be partially controlled by solarization (Bell \& Elmore, 1983; Elmore 1991).

Solarization was found to increase both plant height and fruit yield of tomato. Stapleton, Quick \& De Vay (1985) attributed the favourable influence of solarization on crop performance to, among other things, increased mineralization of organic materials in the soil. Results of the present study seemed to support this claim since solarization narrowed the $C: N$ ratios considerably and, by implication, increased the rate of mineralization.

It would seem that solarization proved lethal to resident thermophylic microbiota thus causing their degradation and the release of nitrogen mainly in the form of $\mathrm{NH}_{4}^{+}-\mathrm{N}^{-}$and $\mathrm{NO}_{3}^{-}-\mathrm{N}$ as reported by Chen\&Katan (1980). Othermineral nutrientsin the soil including extractable $\mathrm{P}, \mathrm{K}, \mathrm{Ca}$, and $\mathrm{Mg}$, were sometimes also found in greater concentration in solarized soil (Stapleton, Quick \& De Vay, 1985). Fruit yield of tomato in solarized soil was further improved through a significant reduction in the incidence of fruit rot.

In conclusion, preliminary indications were that soil solarization, under the environmental conditions prevailing in the coastal scrub and thicket vegetation belt of the Central Region of Ghana during the dry season, was applicable as a control measure of nematodes, and annual weed species. Solarization also improved the nutrient status of the soil and thereby enhanced fruit yield of transplanted tomato. It might be worthwhile to test this innovation in tomato nursery beds to ascertain whether protection could be extended into the field situation.

\section{REFERENCES}

Alkayssi, A. W. \& Alkaraghouli, A. A. (1991) Influence of different colour plastic mulches used for soil solarization on the effectiveness of soil heating. FAO
Plant Production and Protection Paper 109, pp. 297-308.

Asamoah, G. K. (1973) Soils of the proposed farm site of the University of Cape Coast. Soil Res. Inst. Tech. Rep. No. 88.

Bell, C. E. \& Elmore, C. L. (1983) Soil solarization as a weed control method in fall planted cantaloupes: Grenada, Spain. Proc. West. Soc. Weed Sci. 36, 174177.

Black, C. A., Evanas, D. D., White, J. L., Ensminger, L. E. \& Clark, F. E. (1965) Methods of soil analysis, Part 2, p. 1149. Madison, Wis., USA: American Society of Agronomy, Inc.

Brock, T. D. (1978) Thermophylic microorganisms and life at high temperatures. New York: Springer-Verlag.

Chen, Y. \& Katan, J. (1980) Effect of solar heating of soil by transparent polyethylene mulching on their chemical properties. Soil Sci. 130, 271-277.

Dawson, J. R., Johnson, R. A., Adams, P. \& Last, F. T. (1965) Influence of steam/air mixtures, when used for heating soil, on biological and chemical properties that affect seedling growth. Ann. Appl. Biol.56,243251.

De Vay, J. E. (1991) Effect of soil solarization on fungi and bacteria. FAO Plant Production and Protection Paper 109, pp. 79-93.

Elmore, C. L. (1991) Effect of soil solarization on weeds. In FAO Plant Production and Protection Paper 109, pp. 129-138.

FAO (1994) F.A.O. Quart. Bull. Statistics 61, (1994).

Greco, N., Brandonisio, A. \& Elia, F. (1985) Control of Ditylenchus dipsaci, Heterodera carotae and Meloidogyne javanica by solarization. Nematology Mediterranean 13, 191-197.

Kjeldahl, J. (1883) Neue methode zur Bestimmung des Stickstoffs in organisation Korpern Z. Anal. Chem. 22, 366-382.

PPMED(1991)Policy, Planning, Monitoringand Evaluation Department of the Ministry of Food and Agriculture, Ghana. Facts and Figures: 1991.

Pullman, G. S. \& De Vay, J. E. (1982) Effect of soil flooding and paddy rice culture on the survival of Verticillium dahliae and incidence of Verticillium wilt in cotton. Phytopathology 72, 1285-1289.

Stapleton, J. J. \& De Vay, J. E. (1986) Soil solarization: a non-chemical approach for management of plant pathogens and pests. Crop Prot. 5, 190-198.

Stapleton, J. J., Quick, J. \& De Vay, J. E. (1985) Soil solarization: Effect on soil properties, crop fertilization 
and plant growth. Soil Biol. Biochem. 17, 369-373.

Steel, R. G. D \& Torrie, J. J. (1960) Principles and procedures of statistics. New York, Toronto, London: McGraw-HillBookCo.

Sundaram, J. K. (1986) Physiology and growth of thermophylic bacteria, p. 75-XX. In Themophiles:
General, Molecular and Applied Microbiology (ed. T. D. Brock). New York: John Wiley and Sons. Viglierchio, D. R. \& Schmitt, R. V. (1983) On the methodology of nematode extraction from field samples: Comparison of methods for soil extraction. J. Nematol. $15,450-454$. 